\title{
The Effects of Feeding on Hematological and Plasma Biochemical Profiles in Green (Chelonia mydas) and Kemp's Ridley (Lepidochelys kempii) Sea Turtles
}

\author{
Eric T. Anderson, ${ }^{1,2}$ Larry J. Minter, ${ }^{1}$ Elsburgh O. Clarke III, ${ }^{1,2}$ \\ Raymond M. Mroch III, ${ }^{2,3}$ Jean F. Beasley, ${ }^{4}$ and Craig A. Harms ${ }^{1,2}$ \\ ${ }^{1}$ Department of Clinical Sciences, College of Veterinary Medicine, North Carolina State University, Raleigh, NC 27606, USA \\ ${ }^{2}$ Center for Marine Sciences and Technology, North Carolina State University, Morehead City, NC 28557, USA \\ ${ }^{3}$ North Carolina Department of Environment and Natural Resources, Division of Marine Fisheries, Morehead City, NC 28557, USA \\ ${ }^{4}$ Karen Beasley Sea Turtle Rescue and Rehabilitation Center, Topsail Island, NC, 28445, USA
}

Correspondence should be addressed to Craig A. Harms, craig_harms@ncsu.edu

Received 12 February 2011; Accepted 26 April 2011

Academic Editor: Pedro J. Ginel

Copyright (C) 2011 Eric T. Anderson et al. This is an open access article distributed under the Creative Commons Attribution License, which permits unrestricted use, distribution, and reproduction in any medium, provided the original work is properly cited.

In mammals, lipemic blood from sampling too soon after an animal feeds can have substantial effects on biochemical values. Plasma biochemical values in reptiles may be affected by species, age, season, and nutritional state. However, fasting status is not routinely considered when sampling reptile blood. In this paper, we evaluated 2-hour postprandial blood collection in two sea turtle species to investigate the effects of feeding on hematological and plasma biochemical values. Feeding had no significant effects on hematological values in either species, nor did it have an effect on plasma biochemistry values in Kemp's ridley sea turtles. In postprandial green turtles, total protein, albumin, ALP, AST, ALT, amylase, and cholesterol increased significantly, and chloride decreased significantly. Although statistically significant changes were observed, the median percent differences between pre- and postprandial values did not exceed $10 \%$ for any of these analytes and would not likely alter the clinical interpretation.

\section{Introduction}

Green sea turtles (Chelonia mydas) are found in tropical to semitropical waters around the world and are the second most abundant sea turtle found off the Eastern United Sates $[1,2]$. Juvenile green turtles found in coastal waters are in a transition phase from a more carnivorous diet (shrimp, snails, and ctenophores) to a primarily herbivorous diet (sea grasses), which creates a physiological status unique from other sea turtles [3]. Kemp's ridley sea turtles (Lepidochelys kempii) are the smallest and most endangered of all sea turtles. They are found in waters along the eastern coast of North America, ranging from Mexico to as far north as New York and Massachusetts [2]. Kemp's ridley turtles are carnivorous and opportunistic, feeding primarily on crabs, mollusks, and fish [3]. Juvenile green and Kemp's ridley turtles use shallow coastal waters for foraging grounds, making them susceptible to a number of human-induced traumas (e.g., boat strike and fishing interactions) and natural disease processes (e.g., cold-stunning). Hundreds of juvenile turtles are found dead or severely debilitated each year, with many being brought into rehabilitation centers for treatments.

Hematology and plasma biochemistries are valuable for monitoring animal health; however, environmental and procedural factors can have variable affects on reported values. Postprandial blood collection can yield lipemic samples due to increases in serum triglycerides in the form of chylomycrons. Several biochemical analytes change with diet, feeding, and lipemia in a wide range of species, including mammals [4-13], birds [14-19], sharks [20], and reptiles $[21,22]$. The observed alterations in biochemical values have led to recommendations on prephlebotomy fasting times for many species $[4,6,17,19]$. However, few recommendations have been made for reptiles. 
TABle 1: Size data and time in rehabilitation for green $(n=10)$ and Kemp's ridley $(n=10)$ sea turtles investigated for the effects of feeding on hematology and plasma biochemistry profiles.

\begin{tabular}{lcccc}
\hline \multirow{2}{*}{ Analyte } & \multicolumn{3}{c}{ Green sea turtles } & \multicolumn{2}{c}{ Kemp's ridley sea turtles } \\
& Median & Range & Median & Range \\
\hline Weight $(\mathrm{kg})$ & 6.0 & $3.8-9.3$ & 6.4 & $2.5-13.3$ \\
SCL-N $(\mathrm{cm})^{\text {a }}$ & 35.8 & $29.4-47.1$ & 33.3 & $27.9-41.5$ \\
Days in rehabilitation & 284 & $97-468$ & 117 & $49-452$ \\
\hline
\end{tabular}

${ }^{\text {a }}$ Straight carapace length (nuchal notch to pygal notch).

In reptiles, environmental and physiological factors, including season, sex, age, size, and nutritional state, may alter clinical pathology values [22-24]. In sea turtles, hematological and plasma biochemistry values have been investigated for several species [21,25-34], and biochemical values have been shown to be influenced by sex, size, age, health status, and foraging [21, 31, 34-37]. However, there is a paucity of data regarding the effects of postprandial sampling on plasma chemistry analytes in sea turtles, leading to uncertainty in the need for fasting blood samples.

Understanding whether, or how, feeding impacts clinical pathology values in sea turtles would be helpful in both captive and wild settings because of the great uncertainty in knowing when a wild turtle last fed and occasional difficulties fitting sample collection into the management routines and logistics of a rehabilitation or aquarium facility. This study evaluated the effects of postprandial sampling on hematological and plasma biochemical values in green and Kemp's ridley sea turtles.

\section{Materials and Methods}

2.1. Animals and Environment. Ten juvenile green sea turtles and ten juvenile Kemp's ridley sea turtles undergoing rehabilitation for various conditions at the Karen Beasley Sea Turtle Rescue and Rehabilitation Center, Topsail Island, North Carolina, were used for this study. Median and range of weights, straight carapace lengths (nuchal notch to pygal notch), and days in rehabilitation are shown in Table 1. Only turtles that were active, eating well, and not on any major treatments were included. Not all were considered ready for release, as some were still being treated for minor shell lesions (topical treatment) and for being under the desired body condition for release. Turtles were individually housed in variably sized plastic or fiberglass tanks containing filtered saltwater. Larger tanks were plumbed into a communal filtration system with multiple forms of mechanical and biological filtration; smaller tanks were on a daily dump and fill routine. Most of the turtles remained in indoor tanks, but a few were placed in temporary outdoor enclosures during the afternoons to facilitate daily operations of the rehabilitation facility and provide UV light exposure. Water temperatures ranged from $25^{\circ} \mathrm{C}-29^{\circ} \mathrm{C}$.

2.2. Sampling and Feeding. Blood was collected in conjunction with routine health monitoring and prerelease examinations. Initial blood samples were taken first thing in the morning following an approximately $24 \mathrm{hr}$ fast prior to any food items being offered. Turtles were manually restrained on an exam table, and the head was restrained in ventral flexion over the side of the table to facilitate blood collection. A $22 \mathrm{ga} \times 2.54 \mathrm{~cm}$ needle and $3 \mathrm{~mL}$ syringe were heparinized and used to collect $2-3 \mathrm{~mL}$ of blood from the external jugular vein. After initial sampling, the turtles were returned to their holding tanks and offered food. A combination of frozen thawed capelin (Mallotus villosus) with lesser amounts of squid (Loligo sp.), and/or blue crab (Callinectes sapidus) was offered at 1.5\%-9.0\% body weight. Based on proximate analyses of diet items performed previously at this facility (squid and blue crab; Microbac Laboratories, Inc., Southern Testing and Research Division, Wilson, NC, USA) and previously published values for capelin and squid [38], capelin contains a moderate amount of lipid (7.0\%-23.3\% dry matter basis), while squid and blue crab contain a lesser amount of lipid (squid 8.3\%$11.4 \%$, blue crab $2.4 \%$ dry matter basis). All turtles were given $30 \mathrm{~min}$ to feed, and all consumed a minimum of $50 \%$ or more of the diet offered. Two hours after feeding, a second blood sample was collected. For turtles that took longer than $10 \mathrm{~min}$ to consume the offered diet, the time for the postprandial blood sample was calculated from the time the turtle stopped eating or excess food was removed from the tank. The median (range) time from feeding to the postprandial blood draw was $126 \mathrm{~min}$ (113-142 min).

2.3. Blood Processing and Analysis. For each turtle, two blood smears were made, two hematocrit tubes filled, and the remainder of the blood was placed in a sterile $1.5 \mathrm{~mL}$ conical vial with no additive (Fisher Scientific Company, Pittsburgh, $\mathrm{Pa}$, USA) on wet ice until centrifugation. All samples were centrifuged within $67 \mathrm{~min}$ of collection. Hematocrit tubes were centrifuged at $3900 \times \mathrm{g}$ for $5 \mathrm{~min}$, and packed cell volume (PCV) determined. Total solids (TS) were determined by refractometer. The conical vials were centrifuged at $1000 \times \mathrm{g}$ for $10 \mathrm{~min}$, and the plasma harvested. Plasma samples were submitted along with two corresponding blood smears to a commercial diagnostic laboratory (Antech Diagnostics, Memphis, Tenn, USA) for biochemistry analysis and differential blood cell counts within one day of collection. Plasma biochemistry panels were performed on a Hitachi 717 Chemistry Autoanalyzer (Hitachi Instruments Inc., San Jose, Calif, USA). Details on plasma biochemistry assay methodology are summarized elsewhere [39].

2.4. Statistical Analysis. All analyses were performed with JMP 7 (SAS Institute, Cary, NC, USA). Median and range were determined for all hematological and plasma biochemical data. The Wilcoxon matched-pairs signed rank test was used to compare differences between preprandial and postprandial values. The data were then grouped by hematologic values (PCV, \% heterophils, \% lymphocytes, \% monocytes, $\%$ eosinophils, and \% basophils), plasma enzymes (ALP, AST, ALT, CPK, amylase, and lipase), metabolic indicators (total protein, albumin, globulins, glucose, BUN, creatinine, uric acid, cholesterol, triglycerides, and total bilirubin), and ions (sodium, potassium, chloride, calcium, inorganic phosphate, 
TABLE 2: Medians and ranges for preprandial and postprandial plasma biochemical values from juvenile Kemp's ridley sea turtles $(n=10)$. System International and conventional units (in parentheses) are provided.

\begin{tabular}{|c|c|c|c|c|c|}
\hline \multirow{2}{*}{ Analyte } & & \multicolumn{2}{|c|}{ Preprandial } & \multicolumn{2}{|c|}{ Postprandial } \\
\hline & & Median & Range & Median & Range \\
\hline Total protein & $\mathrm{g} / \mathrm{L}(\mathrm{g} / \mathrm{dL})$ & $40(4.0)$ & $34-45(3.4-4.5)$ & $40(4.0)$ & $35-48(3.5-4.8)$ \\
\hline Albumin & $\mathrm{g} / \mathrm{L}(\mathrm{g} / \mathrm{dL})$ & $15(1.5)$ & $13-18(1.3-1.8)$ & $16(1.6)$ & $13-19(1.3-1.9)$ \\
\hline Globulin & $\mathrm{g} / \mathrm{L}(\mathrm{g} / \mathrm{dL})$ & $24(2.4)$ & $20-30(2.0-3.0)$ & $24(2.4)$ & $22-31(2.2-3.1)$ \\
\hline Glucose & $\mathrm{mmol} / \mathrm{L}(\mathrm{mg} / \mathrm{dL})$ & $6.8(122)$ & $5.3-7.3(95-131)$ & $6.4(116)$ & $5.4-8.1(97-145)$ \\
\hline Urea nitrogen & $\mathrm{mmol} / \mathrm{L}(\mathrm{mg} / \mathrm{dL})$ & $43.6(122)$ & $26.4-60.0(74-168)$ & $43.6(122)$ & $27.5-58.9(77-165)$ \\
\hline Creatinine & $\mu \mathrm{mol} / \mathrm{L}(\mathrm{mg} / \mathrm{dL})$ & $18(0.2)$ & $18-26(0.2-0.3)$ & $18(0.2)$ & $18-35(0.2-0.4)$ \\
\hline Cholesterol & $\mathrm{mmol} / \mathrm{L}(\mathrm{mg} / \mathrm{dL})$ & $5.1(198)$ & $2.1-8.5(80-328)$ & $5.2(202)$ & $2.3-8.5(88-329)$ \\
\hline Triglyceride & $\mathrm{mmol} / \mathrm{L}(\mathrm{mg} / \mathrm{dL})$ & $3.8(348)$ & $0.3-7.3(23-662)$ & $3.9(354)$ & $0.3-8.6(25-779)$ \\
\hline Uric Acid & $\mu \mathrm{mol} / \mathrm{L}(\mathrm{mg} / \mathrm{dL})$ & $36(0.6)$ & $6-71(0.1-1.2)$ & $71(1.2)$ & $6-107(0.1-1.8)$ \\
\hline Calcium & $\mathrm{mmol} / \mathrm{L}(\mathrm{mg} / \mathrm{dL})$ & $1.8(7.4)$ & $1.6-2.0(6.5-7.8)$ & $1.8(7.0)$ & $1.6-1.9(6.5-7.7)$ \\
\hline Phosphate & $\mathrm{mmol} / \mathrm{L}(\mathrm{mg} / \mathrm{dL})$ & $2.4(7.6)$ & $1.5-2.9(4.7-8.9)$ & $2.5(7.8)$ & $1.5-2.8(4.8-8.8)$ \\
\hline Sodium & $\mathrm{mmol} / \mathrm{L}$ & 154 & $150-158$ & 155 & $153-164$ \\
\hline Potassium & $\mathrm{mmol} / \mathrm{L}$ & 4.1 & $3.9-4.4$ & 4.4 & $3.6-4.7$ \\
\hline Chloride & $\mathrm{mmol} / \mathrm{L}$ & 127 & $120-131$ & 124 & $120-127$ \\
\hline Magnesium & $\mathrm{mmol} / \mathrm{L}(\mathrm{mg} / \mathrm{dL})$ & $1.7(4.2)$ & $1.2-2.5(3.0-6.1)$ & $1.7(4.2)$ & $1.2-2.3(2.9-5.7)$ \\
\hline $\mathrm{ALP}^{\mathrm{a}}$ & $\mathrm{U} / \mathrm{L}$ & 98 & $40-197$ & 96 & $41-211$ \\
\hline $\mathrm{ALT}^{\mathrm{a}}$ & $\mathrm{U} / \mathrm{L}$ & 6 & $1-35$ & 6 & $0-45$ \\
\hline $\mathrm{AST}^{\mathrm{a}}$ & $\mathrm{U} / \mathrm{L}$ & 491 & $66-3607$ & 523 & $69-4128$ \\
\hline $\mathrm{CK}^{\mathrm{a}}$ & $\mathrm{U} / \mathrm{L}$ & 786 & $370-8289$ & 812 & $361-8166$ \\
\hline Amylase & $\mathrm{U} / \mathrm{L}$ & 528 & $457-699$ & 564 & $462-740$ \\
\hline Lipase & $\mathrm{U} / \mathrm{L}$ & 8 & $0-16$ & 10 & $0-16$ \\
\hline
\end{tabular}

aLP, alkaline phosphatase; ALT, alanine aminotransferase; AST, aspartate aminotransferase; CK, creatine kinase.

and magnesium), and the sequential Bonferroni technique was applied within each group to reduce the chance of type I error [40]. A $P$ value of $<.05$ after sequential Bonferroni correction was considered statistically significant. A median difference of $10 \%$ or greater for an analyte was arbitrarily chosen as a point at which a statistical difference may become clinically relevant and, therefore, may lead to an alteration in the clinical interpretation or therapeutic course.

\section{Results}

There were no significant differences between pre- and postprandial PCV and differentials for either the green turtle or the Kemp's ridley sea turtle (data not shown). There were no significant differences between preprandial and postprandial values in the Kemp's ridley sea turtles (Table 2). In postprandial samples in the green turtles (Table 3 ), there were significant increases in total protein $(P=.0390)$, albumin $(P=.0351)$, alkaline phosphatase (ALP; $P=$ .0156 ), alanine aminotransferase (ALT; $P=.0351$ ), aspartate aminotransferase (AST; $P=.0120)$, amylase $(P=.0100)$, and cholesterol $(P=.0312)$. In addition, there was a significant decrease in chloride $(P=.0234)$. Of these analytes that were statistically different after feeding, none had a median percent difference of greater than $10 \%$ between pre- and postprandial samples (Table 4). Although median percent differences were greater than $10 \%$ for globulin and creatine kinase (CK) in green turtles, and for lipase and uric acid in Kemp's ridley turtles, the variability of data was high, and those differences were not statistically significant.

\section{Discussion}

All hematological and biochemical values for both species of sea turtles were consistent with values previously reported for these species $[25,30,31,35,41-43]$ except for inorganic phosphate, AST, and ALT in the green turtles. Inorganic phosphate was at the upper range or slightly higher than reported values $[25,30,35,41,43]$, which is likely related to diet. The marked elevation in AST and ALT of most of the green turtles, as compared to reported values, is a phenomenon that has previously been observed in this population (unpublished data). The underlying cause is uncertain, but it may also be of dietary origin related to a more carnivorous diet in captivity. Because postprandial values were compared with preprandial values for each turtle, the initial values were not a factor in the analysis.

No significant differences were found between preprandial and postprandial hematological values for either the green turtle or the Kemp's ridley sea turtle. This finding was expected, because postprandial sampling is linked with lipemia and interference with analytes that utilize photometric analyses $[4,5,12,44]$. Hematological values are obtained through direct microscopic evaluation of cell numbers and types; therefore, alterations due to postprandial sampling would not be expected. Lipemia has also been linked with 
TABLE 3: Medians and ranges for preprandial and postprandial plasma biochemical values from juvenile green sea turtles $(n=10)$. System International and conventional units (in parentheses) are provided.

\begin{tabular}{|c|c|c|c|c|c|}
\hline \multirow{2}{*}{ Analyte } & & \multicolumn{2}{|c|}{ Preprandial } & \multicolumn{2}{|c|}{ Postprandial } \\
\hline & & Median & Range & Median & Range \\
\hline Total protein & $\mathrm{g} / \mathrm{L}(\mathrm{g} / \mathrm{dL})$ & $46(4.6)$ & $26-55(2.6-5.5)$ & $49(4.9)^{\mathrm{a}}$ & $25-60(2.5-6.0)$ \\
\hline Albumin & g/L (g/dL) & $19(1.9)$ & $10-25(1.0-2.5)$ & $21(2.1)^{\mathrm{a}}$ & $10-26(1.0-2.6)$ \\
\hline Globulin & $\mathrm{g} / \mathrm{L}(\mathrm{g} / \mathrm{dL})$ & $26(2.6)$ & $16-33(1.6-3.3)$ & $29(2.9)$ & $15-35(1.5-3.5)$ \\
\hline Glucose & $\mathrm{mmol} / \mathrm{L}(\mathrm{mg} / \mathrm{dL})$ & $8.2(146)$ & $5.4-10.3(97-184)$ & $8.3(149)$ & $6.8-9.6(122-171)$ \\
\hline Urea nitrogen & $\mathrm{mmol} / \mathrm{L}(\mathrm{mg} / \mathrm{dL})$ & $30.0(84)$ & $19.3-51.4(54-144)$ & $29.6(83)$ & $19.3-49.6(54-139)$ \\
\hline Creatinine & $\mu \mathrm{mol} / \mathrm{L}(\mathrm{mg} / \mathrm{dL})$ & $18(0.2)$ & $9-18(0.1-0.2)$ & $18(0.2)$ & $18-26(0.2-0.3)$ \\
\hline Cholesterol & $\mathrm{mmol} / \mathrm{L}(\mathrm{mg} / \mathrm{dL})$ & $5.4(207)$ & $2.4-8.1(93-311)$ & $5.5(216)^{\mathrm{a}}$ & $2.4-9.2(93-352)$ \\
\hline Triglyceride & $\mathrm{mmol} / \mathrm{L}(\mathrm{mg} / \mathrm{dL})$ & $1.7(151)$ & $0.9-4.4(83-401)$ & $1.7(154)$ & $0.8-4.8(72-441)$ \\
\hline Uric Acid & $\mu \mathrm{mol} / \mathrm{L}(\mathrm{mg} / \mathrm{dL})$ & $59(1.0)$ & $48-125(0.8-2.1)$ & $89(1.5)$ & 54-137 (0.9-2.3) \\
\hline Calcium & $\mathrm{mmol} / \mathrm{L}(\mathrm{mg} / \mathrm{dL})$ & $1.7(6.8)$ & $1.4-2.0(5.7-7.8)$ & $1.8(7.3)$ & $1.4-2.2(5.5-8.6)$ \\
\hline Phosphate & $\mathrm{mmol} / \mathrm{L}(\mathrm{mg} / \mathrm{dL})$ & $2.9(9.0)$ & $2.0-4.3(6.1-13.2)$ & $3.0(9.3)$ & $2.3-4.4(7.2-13.7)$ \\
\hline Sodium & $\mathrm{mmol} / \mathrm{L}$ & 154 & $148-162$ & 154 & $148-159$ \\
\hline Potassium & $\mathrm{mmol} / \mathrm{L}$ & 4.3 & $3.5-6.7$ & 4.1 & $3.2-5.3$ \\
\hline Chloride & $\mathrm{mmol} / \mathrm{L}$ & 121 & $116-131$ & $116^{\mathrm{a}}$ & $109-122$ \\
\hline Magnesium & $\mathrm{mmol} / \mathrm{L}(\mathrm{mg} / \mathrm{dL})$ & $3.2(6.3)$ & $1.5-3.3(3.7-8.1)$ & $3.1(6.2)$ & $1.7-3.0(4.1-7.4)$ \\
\hline $\mathrm{ALP}^{\mathrm{b}}$ & $\mathrm{U} / \mathrm{L}$ & 54 & $31-63$ & $60^{\mathrm{a}}$ & $32-68$ \\
\hline $\mathrm{ALT}^{\mathrm{b}}$ & $\mathrm{U} / \mathrm{L}$ & 90 & $14-237$ & $108^{\mathrm{a}}$ & 15-285 \\
\hline $\mathrm{AST}^{\mathrm{b}}$ & $\mathrm{U} / \mathrm{L}$ & 1486 & $396-3175$ & $1684^{\mathrm{a}}$ & $438-3491$ \\
\hline $\mathrm{CK}^{\mathrm{b}}$ & $\mathrm{U} / \mathrm{L}$ & 1072 & $145-1802$ & 994 & $208-2540$ \\
\hline Amylase & $\mathrm{U} / \mathrm{L}$ & 1086 & $163-1470$ & $1154^{\mathrm{a}}$ & 194-1531 \\
\hline Lipase & $\mathrm{U} / \mathrm{L}$ & 20 & $2-48$ & 20 & $2-53$ \\
\hline
\end{tabular}

${ }^{a}$ Indicates postprandial values that differ significantly from preprandial values $(P \leq .039)$.

${ }^{b}$ ALP, alkaline phosphatase; ALT, alanine aminotransferase; AST, aspartate aminotransferase; CK, creatine kinase.

increased hemolysis due to red cell fragility [4]; however, little to no hemolysis was observed in any of the samples used.

The green sea turtle showed more postprandial changes in plasma chemistry values than were observed in the Kemp's ridley sea turtle. In the green turtle, total protein, albumin, ALP, AST, ALT, cholesterol, and amylase significantly increased following feeding, but none changed to a degree that would likely lead to alterations in medical management. In the Kemp's ridley sea turtle, there were no significant differences between pre- and postprandial samples. The differences between the two species could relate to differences in their natural diets. Juvenile Kemp's ridley turtles are carnivorous, consuming primarily crustaceans [3], whereas the juvenile green turtles shift from a carnivorous to a more herbivorous lifestyle $[3,45]$. However, in the rehabilitation setting of the current study, both species are primarily fed capelin with some squid, and with many Kemp's ridleys also being fed soft-shell blue crab. The difference observed might then be due to each species' specialized physiology for their natural diet (i.e., inclusion of vegetation in the diet of the juvenile green turtles of this size). Research on the effects of natural diets on plasma biochemical profiles at different life stages is warranted.

The increased values observed in green turtles contrast with what has been observed in the red-eared slider (Trachemys scripta elegans), where no differences in any of these analytes were found in $24 \mathrm{hr}$ and $48 \mathrm{hr}$ postprandial samples [46]. Variable ALP, AST, and ALT activities have been measured in multiple tissues in reptiles, resulting in indeterminate degrees of clinical utility [47-49]. Despite statistically significant increases, none of these enzymes changed substantially (i.e., no median percent differences $>10 \%$ ) in the current study, and both pre- and postprandial ALP values were comparable to published ranges for green sea turtles $[25,30,41-43]$. The initial plasma activity levels for AST and ALT were higher than in previous reports $[25,30,41-43]$, but the median percent postprandial changes were minor $(<10 \%)$. Apartate aminotransferase and ALT have been found in skeletal muscle to some extent $[48,49]$. It is possible that the initial phlebotomy caused mild muscle damage and subsequent leakage of the enzymes from the muscle cells. This leakage of the enzyme into the peripheral circulation could account for mild increases in enzyme activities observed in the postprandial samples. Changes in CK, however, were highly variable and not consistently supportive of the interpretation of muscle damage. These same studies found these three enzymes in liver, kidney and variable concentrations in other organ tissues [48, 49], and postprandial elevations may be indicative of organs gearing up for digestion (e.g., liver, pancreas, and gastrointestinal tract). There are several isoenzymes of these tissue enzymes that may contribute to the overall increase in plasma enzyme activity. Although outside the scope of this paper, evaluation of the isoenzymes would help to better characterize the observed enzyme plasma activities. 
TABle 4: Median \% differences and ranges between postprandial and preprandial plasma biochemical values from juvenile green $(n=10)$ and Kemp's ridley $(n=10)$ sea turtles.

\begin{tabular}{lcccc}
\hline \multirow{2}{*}{ Analyte } & \multicolumn{2}{c}{ Green sea turtles } & \multicolumn{2}{c}{ Kemp's ridley sea turtles } \\
& Median & Range & Median & Range \\
\hline Total protein & 8.5 & $-3.8-21.6$ & 3.7 & $-2.4-17.6$ \\
Albumin & 7.0 & $0-22.2$ & 6.1 & $-7.1-7.7$ \\
Globulin & 11.2 & $-6.2-34.8$ & 4.3 & $-7.7-23.8$ \\
Glucose & 4.9 & $-23.8-25.8$ & -1.8 & $-13.1-16.9$ \\
Urea nitrogen & -1.0 & $-4.9-3.4$ & -0.9 & $-5.9-4.8$ \\
Creatinine & 0 & $0-100$ & 0 & $-33.3-50.0$ \\
Cholesterol & 6.5 & $0-17.5$ & 5.3 & $-2.6-10.0$ \\
Triglyceride & 4.1 & $-25.3-43.3$ & 8.2 & $-11.8-25.1$ \\
Uric Acid & 9.5 & $-11.1-35.7$ & 56.3 & $-83.3-142.9$ \\
Calcium & 6.9 & $-15.1-28.4$ & -2.6 & $-11.5-4.5$ \\
Phosphorus & 3.7 & $-9.5-18.0$ & 2.3 & $-1.1-6.9$ \\
Sodium & 0 & $-3.7-4.1$ & 0.6 & $-1.3-5.1$ \\
Potassium & -8.2 & $-38.8-39.5$ & 3.5 & $-7.7-14.6$ \\
Chloride & -4.6 & $-9.2-0$ & -2.0 & $-4.7-0.8$ \\
Magnesium & 2.9 & $-8.6-10.8$ & -3.3 & $-25.6-13.3$ \\
ALPa & 8.7 & $0-21.1$ & 4.5 & $-9.9-12.9$ \\
ALT & 8.6 & $-2.8-25.3$ & 5.0 & $-100-50$ \\
AST & 9.6 & $1.4-17.1$ & 5.5 & $-3.9-14.4$ \\
CK $^{\mathrm{a}}$ & 46.5 & $-46.2-202.3$ & 6.2 & $-2.4-15.8$ \\
Amylase & 6.5 & $4.0-19.0$ & 5.2 & $-3.7-11.0$ \\
Lipase & 2.3 & $-25.0-33.3$ & 13.9 & $-100-33.3$ \\
\hline ALP, & & & & \\
& & & &
\end{tabular}

${ }^{a}$ ALP, alkaline phosphatase; ALT, alanine aminotransferase; AST, aspartate aminotransferase; CK, creatine kinase.

Cholesterol and triglycerides may be increased in reptiles due to hepatic lipidosis, vitellogenesis, and prehibernation [50]. Pythons exhibited a 50-fold increase in triglycerides and an $80 \%$ increase in cholesterol following a meal [51]; however, no time frame was provided. In red-eared slider turtles fed a high-fat diet, triglycerides increased significantly within 2 days and did not return to normal until 4 days after feeding [52]. There was no evaluation of a normal diet or cholesterol concentrations. In the current study, with a moderate-to-low-fat diet, triglycerides did not increase significantly in either species, and cholesterol significantly increased $2 \mathrm{hr}$ after feeding in the green turtle but not in the Kemp's ridley sea turtles. The postprandial cholesterol concentrations were, however, increased by less than $10 \%$, and were at or minimally above published reference intervals for cholesterol in green turtles [25, 41, 42, 50].

Although sea turtles have a long gastrointestinal transit time (up to 7 or 8 days in the Kemp's ridley turtle [53] and can tolerate a prolonged fast (possibly months for adults of some green turtle populations during reproductive migration) [54]), the 24-hr fast used in this study of juvenile sea turtles is ecologically and physiologically relevant. In the wild, green turtles on foraging grounds feed once to twice daily, and primarily during the daylight hours $[3,55,56]$. In Hawaii, green turtles have been found to feed primarily at night in some areas, where they foraged from evening twilight to around sunrise [57]. Green turtles in areas of poor food availability, highly disturbed grass beds, fed more continuously (approximately $9 \mathrm{hr}$ ) during daylight hours [58]. Kemp's ridley sea turtles feed primarily on more active and mobile prey such as crabs $[3,53,59-61]$ and, therefore likely feed more sporadically throughout the day [61]. As a result of their natural feeding behaviors, a $24-\mathrm{hr}$ period without food constitutes a valid fast for these two species.

None of the changes observed in hematologic and plasma chemistry values between pre- and $2 \mathrm{hr}$ postprandial blood samples were considered sufficient to revise a clinical interpretation or trigger a change in an animal's course of treatment. It is possible that a longer preprandial fast, or following biochemical profiles for a longer period of time after feeding, would yield greater alterations. However, for a juvenile green or Kemp's ridley sea turtle feeding once daily, there is little consequence to sampling $2 \mathrm{hr}$ postprandial versus after a 24 -hr fast. Timing of blood collection in regularly feeding sea turtles appears to be less critical for interpretation of clinical pathology values than in some other species.

\section{Acknowledgments}

The authors thank all the volunteers at the Karen Beasley Sea Turtle Rescue and Rehabilitation Center for their dedication and work with sick and injured sea turtles and for their help with the turtles during this study. They also thank two classes of veterinary students for technical assistance with sample collection and processing.

\section{References}

[1] S. P. Epperly, J. Braun, and A. Veishlow, "Sea turtles in North Carolina waters," Conservation Biology, vol. 9, no. 2, pp. 384394, 1995.

[2] P. C. H. Pritchard, "Evolution, phylogeny, and current status," in The Biology of Sea Turtles, P. L. Lutz and J. A. Musick, Eds., pp. 1-28, CRC Press, 1997.

[3] K. A. Bjorndal, "Foraging ecology and nutrition of sea turtles," in The Biology of Sea Turtles, P. L. Lutz and J. A. Musick, Eds., pp. 199-231, CRC Press, 1997.

[4] A. R. Alleman, "The effects of hemolysis and lipemia on serum biochemical constituents," Veterinary Medicine, vol. 85, no. 12, pp. 1272-1284, 1990.

[5] R. M. Jacobs, J. H. Lumsden, and E. Grift, "Effects of bilirubinemia, hemolysis, and lipemia on clinical chemistry analytes in bovine, canine, equine, and feline sera," Canadian Veterinary Journal, vol. 33, no. 9, pp. 605-608, 1992.

[6] V. P. Kale, G. S. Joshi, P. B. Gohil, and M. R. Jain, "Effect of fasting duration on clinical pathology results in Wistar rats," Veterinary Clinical Pathology, vol. 38, no. 3, pp. 361-366, 2009.

[7] R. Lucena, P. Moreno, A. Pérez-Rico, and P. J. Ginel, "Effects of haemolysis, lipaemia and bilirubinaemia on an enzyme-linked immunosorbent assay for cortisol and free thyroxine in serum samples from dogs," Veterinary Journal, vol. 156, no. 2, pp. 127-131, 1998.

[8] S. Martínez-Subiela, F. Tecles, A. Montes, C. Gutiérrez, and J. J. Cerón Madrigal, "Effects of haemolysis, lipaemia, bilirubinaemia and fibrinogen on protein electropherogram of canine samples analysed by capillary zone electrophoresis," Veterinary Journal, vol. 164, no. 3, pp. 261-268, 2002. 
[9] D. J. Meyer and J. W. Harvey, Veterinary Laboratory Medicine: Interpretation \& Diagnosis, W. B. Saunders, 2nd edition, 1998.

[10] A. Mori, T. Sako, P. Lee et al., "Comparison of three commercially available prescription diet regimens on shortterm post-prandial serum glucose and insulin concentrations in healthy cats," Veterinary Research Communications, vol. 33, no. 7, pp. 669-680, 2009.

[11] A. A. Njidda and C. E. Isidahomen, "Haematology, blood chemistry and carcass characteristics of growing rabbits fed grasshopper meal as a substitute for fish meal," Pakistan Veterinary Journal, vol. 30, no. 1, pp. 7-12, 2009.

[12] J. B. Tasker, "Studies on the use of Coulter chemistry in the veterinary laboratory: day- to-day reproducibility and the effects of storage, hemolysis, lipemia, hyperbilirubinemia, and anticoagulants on test results," Cornell Veterinary, vol. 68, no. 4, pp. 480-505, 1978.

[13] A. D. Watson, D. B. Church, and A. J. Fairburn, "Postprandial changes in plasma urea and creatinine concentrations in dogs," American Journal of Veterinary Research, vol. 42, no. 11, pp. 1878-1880, 1981.

[14] J. A. Amat, F. Hortas, G. M. Arroyo et al., "Interannual variation in feeding frequencies and food quality of greater flamingo chicks (Phoenicopterus roseus): evidnce from plasma chemistry and effects on body condition," Comparative Biochemsitry and Physiology A, vol. 147, no. 2, pp. 569-576, 2007.

[15] J. Buyse, K. Janssens, S. Der Geyten, P. Van As, E. Decuypere, and V. M. Darras, "Pre- and postprandial changes in plasma hormone and metabolite levels and hepatic deiodinase activities in meal-fed broiler chickens," British Journal of Nutrition, vol. 88 , no. 6, pp. 641-653, 2002.

[16] C. Cray and A. Andreopoulos, "Comparison of two methods to determine plasma bile acid concentrations in healthy birds," Journal of Avian Medicine and Surgery, vol. 17, no. 1, pp. 11$15,2003$.

[17] C. Cray, D. W. Stremme, and K. L. Arheart, "Postprandial biochemistry changes in penguins (Spheniscus demersus) including hyperuricemia," Journal of Zoo and Wildlife Medicine, vol. 41, no. 2, pp. 325-326, 2010.

[18] I. Fischer, C. Christen, H. Lutz, H. Gerlach, M. Hässig, and J. M. Hatt, "Effects of two diets on the haematology, plasma chemistry and intestinal flora of budgerigars (Melopstittacus undulatus)," Veterinary Record, vol. 159, no. 15, pp. 480-484, 2006.

[19] J. T. Lumeij and J. D. Remple, "Plasma urea, creatinine and uric acid concentrations in relation to feeding in peregrine falcons (Falco peregrinus)," Avian Pathology, vol. 20, no. 1, pp. 79-83, 1991.

[20] C. M. Wood, P. J. Walsh, M. Kajimura, G. B. McClelland, and S. F. Chew, "The influence of feeding and fasting on plasma metabolites in the dogfish shark (Squalus acanthias)," Comparative Biochemistry and Physiology A, vol. 155, no. 4, pp. 435-444, 2010.

[21] S. L. Deem, T. M. Norton, M. Mitchell et al., "Comparison of blood values in foraging, nesting, and stranded loggerhead turtles (Caretta caretta) along the coast of Georgia, USA," Journal of Wildlife Diseases, vol. 45, no. 1, pp. 41-56, 2009.

[22] J. M. Maixner, E. C. Ramsay, and L. H. Arp, "Effects of feeding on serum uric acid in captive reptiles," Journal of Zoo Animal Medicine, vol. 18, no. 2-3, pp. 62-65, 1987.

[23] K. Lawrence, "Seasonal variation in blood biochemistry of long-term captive Mediterranean tortoises (Testudo graeca and Thermanni)," Research in Veterinary Science, vol. 43, no. 3, pp. 379-383, 1987.
[24] J. H. Samour, C. M. Hawkey, S. Pugsley, and D. Ball, "Clinical and pathological findings related to malnutrition and husbandry in captive giant tortoises (Geochelone species)," The Veterinary Record, vol. 118, no. 11, pp. 299-302, 1986.

[25] A. B. Bolten and K. A. Bjorndal, "Blood profiles for a wild population of green turtles (Chelonia mydas) in the southern Bahamas: size-specific and sex-specific relationships," Journal of Wildlife Diseases, vol. 28, no. 3, pp. 407-413, 1992.

[26] A. B. Casal, M. Camacho, L. F. López-Jurado, C. Juste, and J. Orós, "Comparative study of hematologic and plasma biochemical variables in Eastern Atlantic juvenile and adult nesting loggerhead sea turtles (Caretta caretta)," Veterinary Clinical Pathology, vol. 38, no. 2, pp. 213-218, 2009.

[27] A. B. Casal and J. Orós, "Morphologic and cytochemical characteristics of blood cells of juvenile loggerhead sea turtles (Caretta caretta)," Research in Veterinary Science, vol. 82, no. 2, pp. 158-165, 2007.

[28] A. B. Casal and J. Orós, "Plasma biochemistry and haematology values in juvenile loggerhead sea turtles undergoing rehabilitation," Veterinary Record, vol. 164, no. 21, pp. 663665, 2009.

[29] S. L. Deem, E. S. Dierenfeld, G. P. Sounguet et al., "Blood values in free-ranging nesting leatherback sea turtles (Dermochelys coriacea) on the coast of the Republic of Gabon," Journal of Zoo and Wildlife Medicine, vol. 37, no. 4, pp. 464471, 2006.

[30] M. Flint, J. M. Morton, C. J. Limpus, J. C. Patterson-Kane, P. J. Murray, and P. S. Mills, "Development and application of biochemical and haematolgical reference intervals to identify unhealthy green sea turtles (Chelonia mydas)," Veterinary Journal, vol. 185, no. 3, pp. 299-304, 2010.

[31] C. J. Innis, J. B. Ravich, M. F. Tlusty et al., "Hematologic and plasma biochemical findings in cold-stunned Kemp's ridley turtles: 176 cases (2001-2005)," Journal of the American Veterinary Medical Association, vol. 235, no. 4, pp. 426-432, 2009.

[32] J. E. Snoddy, M. Landon, G. Blanvillain, and A. Southwood, "Blood biochemistry of sea turtles captured in gillnets in the lower Cape Fear River, North Carolina, USA," Journal of Wildlife Management, vol. 73, no. 8, pp. 1394-1401, 2009.

[33] J. H. Samour, J. C. Howlett, C. Silvanose, C. R. Hasbun, and S. M. Al-Ghais, "Normal haematology of free-living green sea turtles (Chelonia mydas) from the United Arab Emirates," Comparative Haematology International, vol. 8, no. 2, pp. 102107, 1998.

[34] F. E. Wood and G. K. Ebanks, "Blood cytology and hematology of the green sea turtle, Chelonia mydas," Herpetologica, vol. 40, no. 3, pp. 331-336, 1984.

[35] C. E. Carminati, E. Gerle, L. L. Kiehn, and R. P. Pisciotta, "Blood chemistry comparison of healthy vs hypothermic juvenile Kemp's ridley sea turtles (Lepidochelys kempi) in the New York Bight," in Proceedings of the 14th Annual Symposium of Sea Turtle Biology and Conservation, NOAA Technical Memorandum, pp. 203-207, NMFS-SEFSC-351, 1994.

[36] C. J. Innis, M. Tlusty, C. Merigo, and E. S. Weber, "Metabolic and respiratory status of cold-stunned Kemp's ridley sea turtles (Lepidochelys kempii)," Journal of Comparative Physiology $B$, vol. 177 , no. 6, pp. 623-630, 2007.

[37] M. Santoro and A. Meneses, "Haematology and plasma chemistry of breeding olive ridley sea turtles (Lepidochelys olivacea)," Veterinary Record, vol. 161, no. 24, pp. 818-819, 2007. 
[38] J. B. Bernard and M. E. Allen, Feeding Captive Piscivorous Animals: Nutritional Aspcts of Fish as Food, American Zoo and Aquarium Association: Nutrition Advisory Group Handbook, Fact Sheet 005, 2002.

[39] K. N. Wolf, C. A. Harms, and J. E. Beasley, "Evaluation of five clinical chemistry analyzers for use in health assessment in sea turtles," Journal of the American Veterinary Medical Association, vol. 233, no. 3, pp. 470-475, 2008.

[40] W. R. Rice, “Analyzing tables of statistical tests," Evolution, vol. 43, no. 1, pp. 223-225, 1989.

[41] A. A. Aguirre, G. H. Balazs, T. R. Spraker, and T. S. Gross, "Adrenal and hematological responses to stress in juvenile green turtle (Chelonia mydas) with and without fibropapillomas," Physiological Zoology, vol. 68, no. 5, pp. 831-854, 1995.

[42] C.-L. Fong, H.-C. Chen, and I.-J. Cheng, "Blood profiles from wild populations of green sea turtles in Taiwan," Journal of Veterinary Medicine and Animal Health, vol. 2, no. 2, pp. 008010, 2010.

[43] M. Hamann, C. S. Schäuble, T. Simon, and S. Evans, "Demographic and health parameters of green sea turtles Chelonia mydas foraging in the Gulf of Carpentaria, Australia," Endangered Species Research, vol. 2, pp. 81-88, 2006.

[44] M. J. Murray, "Reptilian Laboratory Medicine," in Laboratory Medicine: Avian and Exotic Pets, A. M. Fudge, Ed., pp. 185192, W. B. Saunders, 2000.

[45] K. J. Reich, K. A. Bjorndal, and A. B. Bolten, "The 'lost years' of green turtles: using stable isotopes to study cryptic lifestages," Biology Letters, vol. 3, no. 6, pp. 712-714, 2007.

[46] Z. Knotkova, G. M. Dorrestein, V. Jekl, J. Janouskova, and Z. Knotek, "Fasting and postprandial serum bile acid concentrations in 10 healthy female red-eared terrapins (Trachemys scripta elegans)," Veterinary Record, vol. 163, no. 17, pp. 510514, 2008.

[47] T. W. Campbell, "Clinical pathology of reptiles," in Reptile Medicine and Surgery, D. R. Mader, Ed., pp. 453-470, Saunders Elservier, 2006.

[48] E. C. Ramsay and T. K. Dotson, "Tissue and serum enzyme activities in the yellow rat snake (Elaphe obsoleta quadrivitatta)," American Journal of Veterinary Research, vol. 56, no. 4, pp. 423-428, 1995.

[49] R. A. Wagner and R. Wetzel, "Tissue and plasma enzyme activities in juvenile green iguanas," American Journal of Veterinary Research, vol. 60, no. 2, pp. 201-203, 1999.

[50] S. J. Divers, "Reptilian liver and gastrointestinal testing," in Laboratory Medicine: Avian and Exotic Pets, A. M. Fudge, Ed., pp. 205-209, W. B. Saunders, 2000.

[51] S. M. Secor and T. R. Nagy, "Postprandial response of plasma lipids and the hormone leptin in pythons [abstract]," American zoologist, vol. 40, no. 6, p. 1205, 2000.

[52] W. Cain, L. Song, G. Stephens, and D. Usher, "Characterization of lipoproteins from the turtle, Trachemys scripta elegans, in fasted and fed states," Comparative Biochemistry and Physiology A, vol. 134, no. 4, pp. 783-794, 2003.

[53] V. J. Burke, S. J. Morreale, and E. A. Standora, "Diet of the Kemp's ridley sea turtle, Lepidochelys kempii, in New York," Fishery Bulletin, vol. 92, no. 1, pp. 26-32, 1994.

[54] G. C. Hays, A. C. Broderick, F. Glen, and B. J. Godley, "Change in body mass associated with long-term fasting in a marine reptile: the case of green turtles (Chelonia mydas) at Ascension Island," Canadian Journal of Zoology, vol. 80, no. 7, pp. 1299 1302, 2002.
[55] K. A. Bjorndal, "Nutrition and grazing behavior of the green turtle Chelonia mydas," Marine Biology, vol. 56, no. 2, pp. 147154, 1980.

[56] J. C. Ogden, L. Robinson, K. Whitlock, H. Daganhardt, and R. Cebula, "Diel foraging patterns in juvenile green turtles (Chelonia mydas) in St. Croix United States virgin islands," Journal of Experimental Marine Biology and Ecology, vol. 66, no. 3, pp. 199-205, 1983.

[57] G. H. Balazs, R. G. Forsyth, and A. K. H. Kam, Preliminary Assessment of Habitat Utilization by Hawaiian Green Turtles in Their Resident Foraging Pastures, NOAA Technical Memorandum, NOAA-TM-NMFS-SWFC-71, Honolulu, Hawaii, USA, 1987.

[58] S. L. Williams, "Thalassia testudinum productivity and grazing by green turtles in a highly disturbed seagrass bed," Marine Biology, vol. 98, no. 3, pp. 447-455, 1988.

[59] V. J. Burke, E. A. Standora, and S. J. Morreale, "Diet of juvenile Kemp's Ridley and loggerhead sea turtles from Long Island, New York," Copeia, no. 4, pp. 1176-1180, 1993.

[60] R. Márquez-M, Synopsis of Biological Data on the Kemp's Ridley Turtle, Lepidochelys kempii (Garman, 1880), NOAA Technical Memorandum, NMFS-SEFSC-343, Miami, Fla, USA, 1994.

[61] J. R. Schmid, A. B. Bolten, K. A. Bjorndal, and W. J. Lindberg, "Activity patterns of Kemp's ridley turtles, Lepidochelys kempii, in the coastal waters of the Cedar Keys, Florida," Marine Biology, vol. 140, no. 2, pp. 215-228, 2002. 

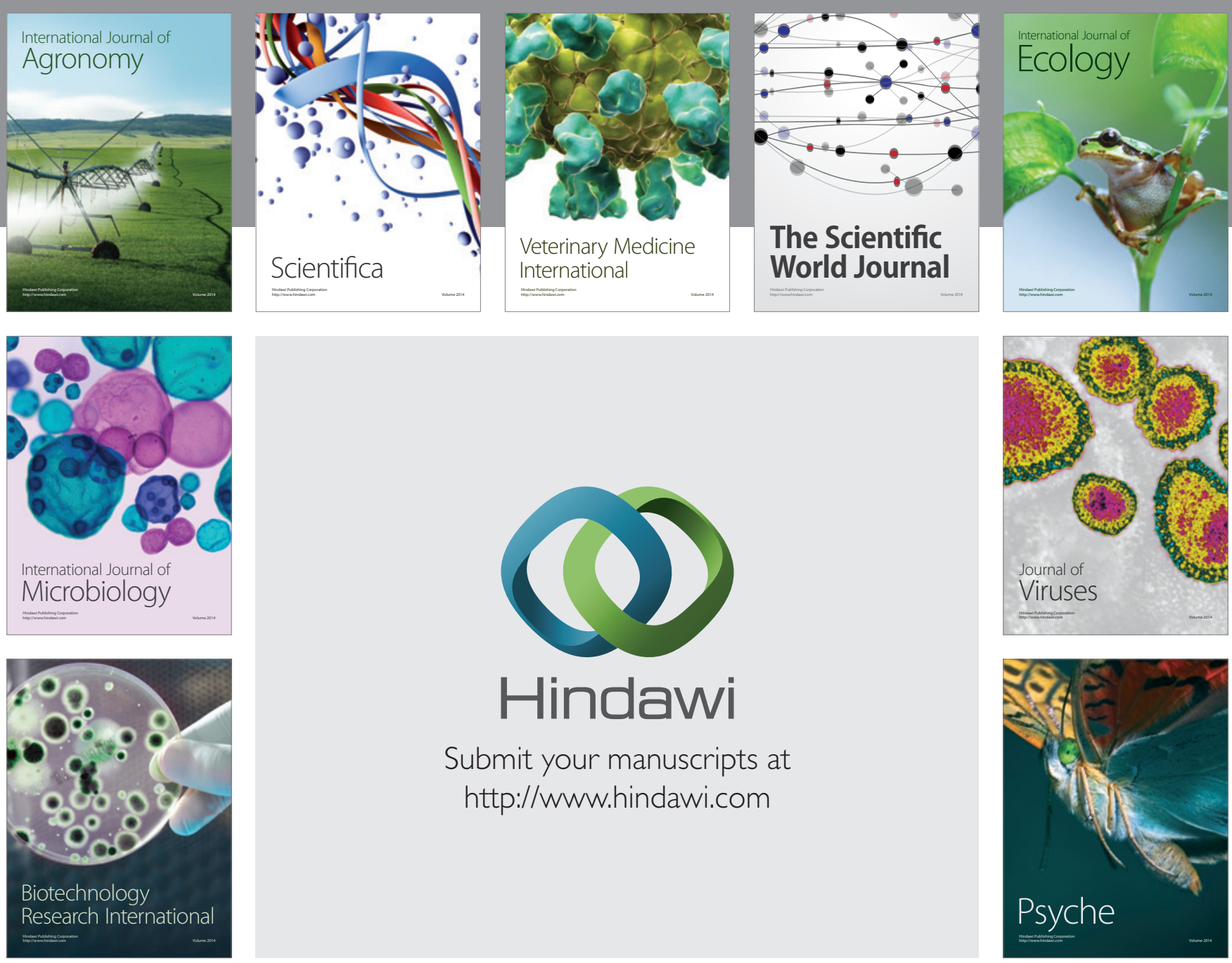

Submit your manuscripts at

http://www.hindawi.com
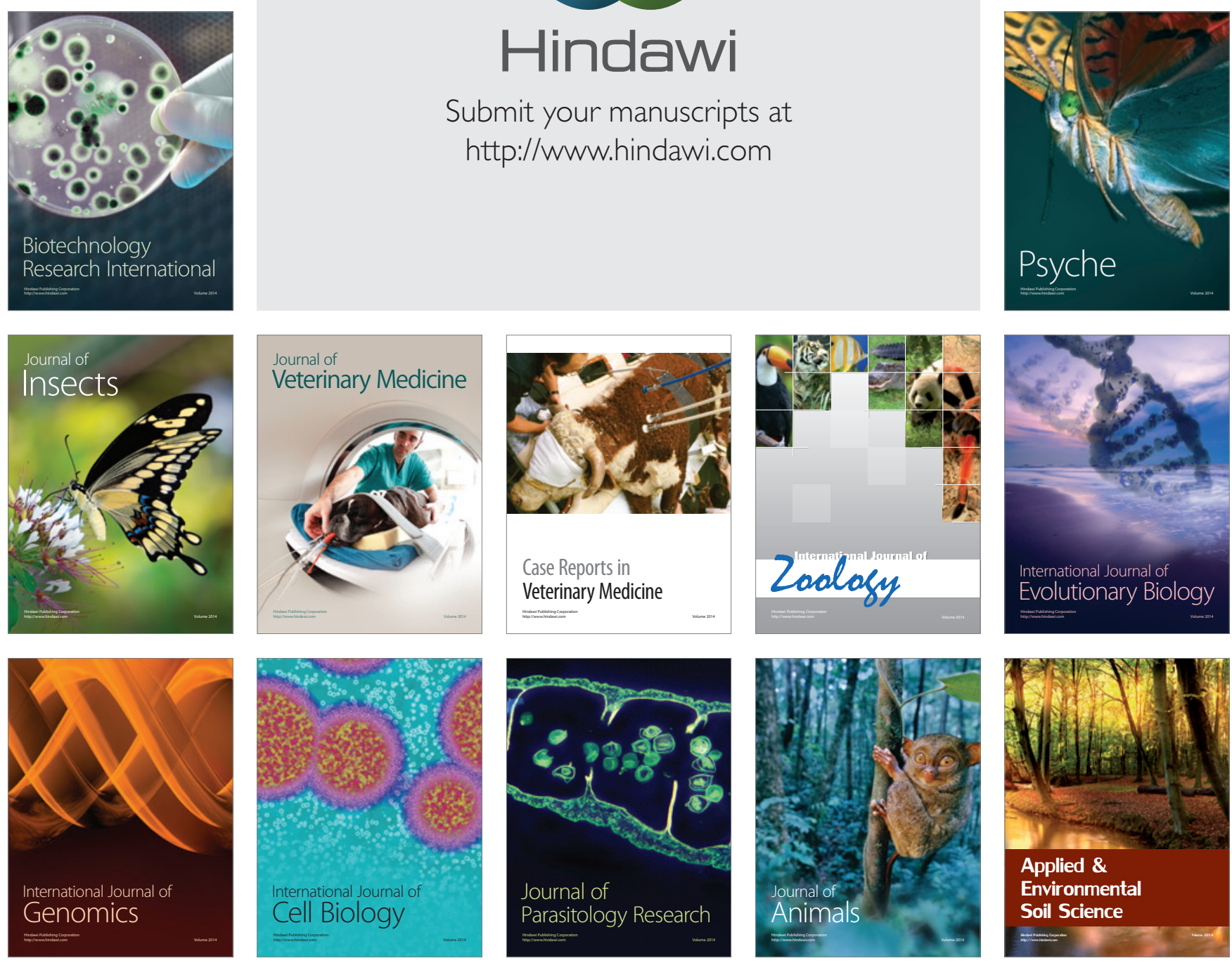